Article

\title{
Managerial Practitioners' Perspectives on Quality Performance of Green-Building Projects
}

\author{
Ayman M. Raouf and Sami G. Al-Ghamdi *(B) \\ Division of Sustainable Development, College of Science and Engineering, Hamad Bin Khalifa University, \\ Qatar Foundation, Doha 34110, Qatar; araouf@mail.hbku.edu.qa \\ * Correspondence: salghamdi@hbku.edu.qa; Tel.: +974-4454-2833; Fax: +974-4454-02811
}

Received: 11 February 2020; Accepted: 28 March 2020; Published: 3 April 2020

\begin{abstract}
The quality performance of a green building will have an overarching effect on its objectives because of the high compliance needed to achieve superior performance expectations. Achieving sustainability objectives is challenging and requires the collaboration of diverse professionals that resume unique responsibilities. In this study, the different managerial practitioners involved in green-building projects were investigated in terms of their awareness levels regarding the quality performance measures, their perceived abilities to influence quality failure consequences, the degree to which the cost-of-quality (CoQ) of components can be evaluated, and the effect the sustainability traits have on the quality performance. Accordingly, a survey approach was adopted, and the results were analyzed using Pearson's chi-squared $\left(\chi^{2}\right)$ test, the relative importance index (RII), Mann-Whitney U-Test, and Student's T-test. According to the results, the priorities of the different managerial types and their overall impressions of cost computability were different, which needs to be considered when CoQ evaluations are done based on practitioners' views. In addition, the sustainability traits of green buildings impact achieving quality metrics with the consequences of design rework occurring in the construction stage may lead to denouncing sustainability traits. The results of this research study reveal the need to consider the differences between managerial types when evaluating CoQ for projects and the increased sensitivity for such evaluation in a green building context. The paper contributes to underscoring the important connection between quality performance and sustainability traits of a green building project and calls for researchers to formulate methods with more rigor to reach a set structure for quality cost accounting as an industry standard. Intricate evaluation methods will enable strategic decision making on quality performance budgets to be more substantiated.
\end{abstract}

Keywords: green buildings; quality performance; sustainability; construction industry

\section{Introduction}

Green buildings typically have three fundamental goals: minimizing environmental impact, improving the health and wellbeing of occupants, and providing a return on investment to the clients and stakeholders under a life cycle approach. The extent to which a green building meets its performance expectations during operation depends on the effectiveness of the design and construction phases. Quality performance is a domain that measures the extent a building conforms to its specifications. The construction industry uses the cost-of-quality (CoQ) method to evaluate the optimal costs incurred when the quality performance requirements are achieved as such optimal costs may be associated with cost-overruns faced in green-building projects. Studies have already undergone assessing economic incentives to reignite the traction towards implementing green buildings in the market and underlined how cost-elastic developers are to implementing green buildings [1,2]. The compliance to quality performance can reveal indications on how to be more cost efficient in adhering to compliance requirements. Green buildings inherently face greater complex design 
iterations, more rigorous simulations and analyses, and greater demands on the construction codes [3]. In addition, green buildings undergo advanced commissioning which is a quality process commencing from design, continuing into construction and a one year minimum of operation which documents and verifies that all the building systems are interactively performing to meet the design intent and owner's expectations [4]. The expectations in a green building are more elevated as there are energy and water saving requirements, improved indoor environmental quality and compliance for environmentally conscious material selection and waste reduction. However, several authors pointed out green buildings did not meet the energy and water savings performances in the operational phases [5-8], nor on indoor environmental quality in actually promoting the building end-users' well-being $[9,10]$. Furthermore, the green building rating systems had a slight impact on tackling construction waste management as a result of weak appraisal measures [11].

The United States Green Building Council (USGBC) attributed the poor construction practices and improper commissioning as part of the reasons for green buildings to underperform from what they were designed for [12]. The significance of the research is to underscore the role of quality performance has on green buildings and reveal the status quo based on managerial perspectives on their perceptions on quality performance and its implications on the green building delivery.

\subsection{Quality Performance in Construction Industry}

Reeves and Bednar (1994) investigated how quality in industry was defined, and deduced the dimensions of the following: value (i.e., a product's intrinsic worth to end-users reflected in the selling price); conformance to requirements and specifications (i.e., the extent to which a product meets the design specifications); meeting and/or exceeding customer expectations (i.e., the perspective of the end-user on the judgment of a product); and fitness for use and loss avoidance (i.e., suitability of the product to the end-user's purpose, minimizing contingencies to achieve such fitness) [13]. This corroborates the assertion made by Juran et al. (1974) that it should not be assumed that customer needs have been merged with specifications [14]. They further argued that despite having a product with good quality features and greater cost investments, the process of overcoming defects leading to rework could prevent financial repercussions caused by such effects [14]. Love and Edwards (2004) examined the definition of construction rework and defined it as any "unnecessary effort of re-doing a process or activity that was incorrectly implemented the first time", which should be rectified [15]. The implications of rework include cost overruns between $1 \%$ and $20 \%$ of the project's original value, schedule delays, productivity losses, reduced profitability, more safety incidents, and reputational damages [16-18]. Poor quality of the building as an end-product can cause proneness to building dilapidation with deteriorating conditions even expanding towards energy and water inefficiencies and potential health hazards $[19,20]$. Post-occupancy evaluation surveys have indicated that green certified buildings are prone to be less sustainable over time with reduced energy and water savings [21]. Building codes have reacted to the poor quality through reinforcing more stringent efficiency measures such as thicker building envelopes [22], but without addressing the actual quality performance in the building process.

\subsection{Measuring Quality}

The cost-of-quality (CoQ) provides a quantitative analysis of expenses incurred by companies for achieving a quality that meets stakeholder requirements at optimal costs. The evaluation of the conformance cost (i.e., proactive-based cost of preventing poor quality) and non-conformance cost (i.e., reactive-based costs of rectifying poor product quality) enable leaders to determine the costs necessary to achieve the desired quality. The CoQ enables quantifying the quality performance; it is used by organizations to optimize costs and determine the activities required to enhance quality. Moreover, the CoQ aligns areas requiring further improvement and justifies quality strategies financially. Several studies have used the CoQ to evaluate construction projects with the Prevention-Appraisal-Failure 
(PAF) model [23-25]. The PAF model operates on the premise that investments in prevention and appraisal activities have a cascading effect on the failure costs.

\subsection{Objectives}

A typical green-building project involves several managerial domains, and each domain has a unique role that requires collaboration and teamwork to meet the green-building objectives. It is argued that the effectiveness of quality delivery depends on the interactions between different managerial domains and on the degree of harmonization of the managerial objectives. The review of literature conducted in this study highlighted the importance of quality performance and how it is measured in regular buildings. Green buildings have elevated performance expectations that need to be adhered to and requires an integrated approach between the teams in its delivery process [26,27]. There are greater design and construction complexities that must be fulfilled and any compromise in quality can have the potential to jeopardize achieving the sustainability requirements [28,29]. There is, however, limited research work done investigating the green building practice from a quality performance perspective and its implications on achieving a sustainability level expectation that was covered in the design [30]. To tackle this research gap, a questionnaire-based approach was used to capture the perspectives of managerial practitioners in green buildings to achieve the following objectives: (1) Determine the differences in perception and behaviors of managerial types towards quality performance; (2) investigate the relationship between quality performance and green building sustainability characteristics. For the first objective, the research will determine their awareness of quality performance, their prioritization of quality failure consequences, and their perceived abilities to influence them, the degree to which preventative, appraisal, and rework actions can be evaluated based on costs. The second objective considers the correlation of quality performance key performance indicators (KPIs) are embedded in sustainability characteristics of a green building project. The rationale behind the research objectives is from the challenge of cost and schedule overruns reported on green buildings, that was reported in several studies [30-35], may lead to hastiness in delivery as the project progresses and ultimately cause quality tradeoffs to happen similar to regular buildings [36]. This may extend into sustainability goals being sidestepped as part of the quality tradeoff. Therefore, a study which captures managerial perspectives on quality performance in a green building context will discern such vulnerabilities on how resolute quality performance is adhered to. The managerial practitioners chosen for the study were managers involved in green-building construction and operation. The diversity of stakeholders (client representatives, consultants, and contractors) were represented.

\section{Methodology}

First-hand information was collected from many managerial practitioners from the construction industry. To ensure objectivity and the standardization of the engagement, a closed, structured, and numerical questionnaire survey was conducted [37]. Figure 1 shows the survey distribution process similar to what was done by Issa (2010) [38]. 


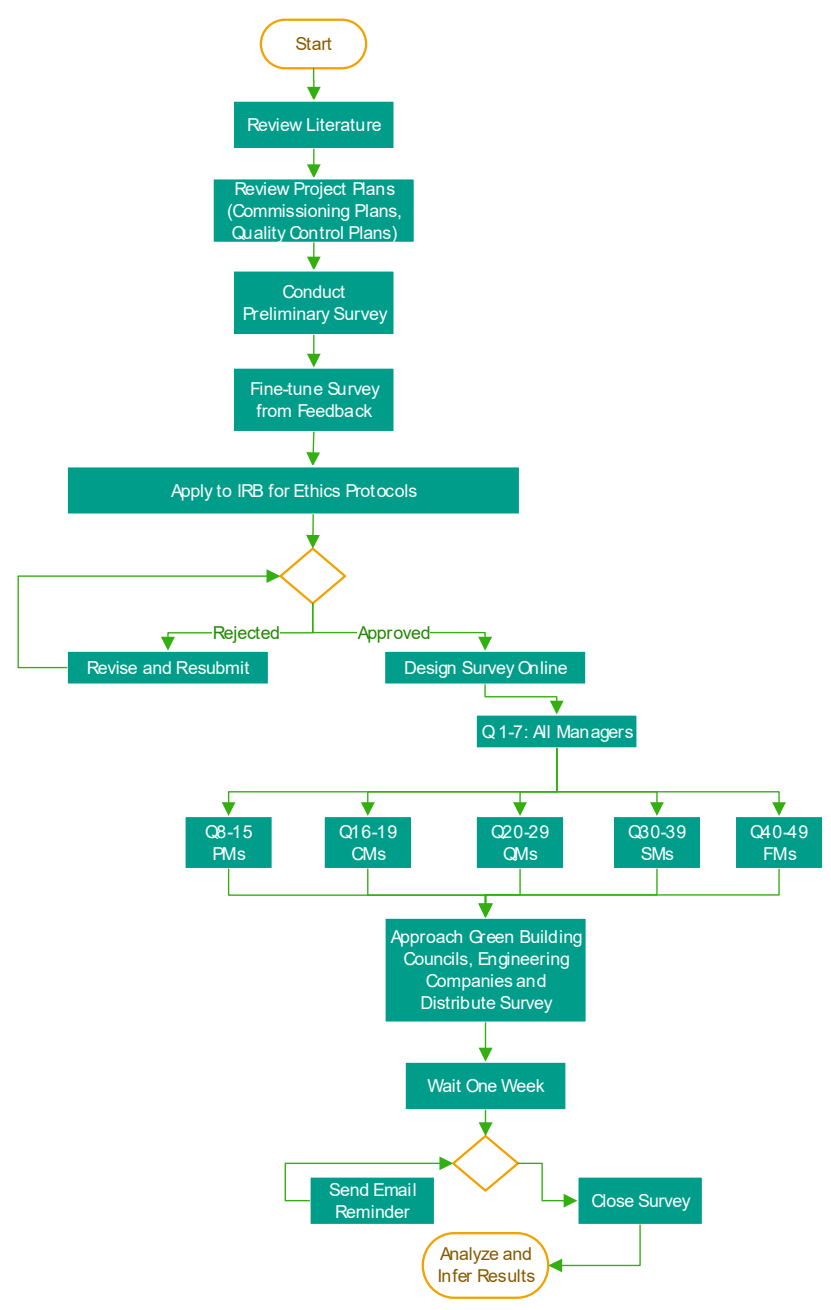

Figure 1. Distribution process.

\subsection{Questionnaire Design}

The authors first determined the management population involved in green-building projects. Therefore, green-building practitioners in Qatar were interviewed to determine the main managerial roles. Accurate descriptions of the project roles were obtained from sustainability and quality management plans. Table 1 shows the different types of managers, their roles, and questions asked to each managerial type (some questions were repeated to different managerial types for comparison). The questionnaire framework (see supplementary material) starts with an explanation of the survey objectives, thereby specifying why the participant was chosen and declaring that there are no risks involved in participating and assuring confidentiality. The second part includes questions characterizing manager respondent demographics in terms of years of experience, geographical location, project lifecycle phase, level of education, and representative firms. The third part of the questionnaire is tailored to each management domain; up to a maximum of 10 questions with specific topics were prepared to determine manager awareness of quality control and assurance, and to determine how they rank their perception of various quality failure consequences. In addition, questions for the third objective were prepared to determine whether elements in the CoQ model are easily deducible or feasible regarding the cost evaluations. Finally, the correlations between sustainability and quality were assessed as a part of the forth objective by determining the current sustainability traits embedded in the quality key performance indicators (KPIs), the consequence of non-compliance of sustainability traits in the rework type, and the degree of integration among teams for formulating the commissioning scope. The questions formulated for each of the managerial types are based on their roles and responsibilities, 
and the KPIs reflect the green-building projects' quality and sustainability plans and PAF quality activities deduced from literature $[5,7,10,17,23]$. Table 2 lists the sources of the different quality failure consequence types.

Table 1. Question structure, managerial roles of participants, and subject targeted.

\begin{tabular}{|c|c|c|}
\hline $\begin{array}{c}\text { Questions: } \\
\text { Respondent \& Type }\end{array}$ & Managerial Role & Subjects \\
\hline $\begin{array}{l}\text { Q 1-7, All Managers: } \\
\text { Multiple Choice }\end{array}$ & $\begin{array}{l}\text { Collective effort of all managers to deliver the project } \\
\text { within the budget of the agreed baseline schedule } \\
\text { and conform to the standards and requirements of } \\
\text { the project specifications and the green-building } \\
\text { rating-system credits planned at project inception. }\end{array}$ & $\begin{array}{l}\text { Respondents' education } \\
\text { background, industry, } \\
\text { and green-building experience; } \\
\text { geographical exposure of } \\
\text { experience, represented entity, } \\
\text { and project phases. }\end{array}$ \\
\hline $\begin{array}{l}\text { Q 8-15, PMs: } \\
\text { Ranking and Multiple } \\
\text { Choice } \\
\text { Statistical Test: Pearson's } \\
\text { Chi Squared, Relative } \\
\text { Importance Index }\end{array}$ & $\begin{array}{l}\text { Manager leadership for ensuring that the project's } \\
\text { financial and schedule goals are met, administering } \\
\text { contractual requirements, managing potential risks, } \\
\text { liaising with client stakeholders in their needs and } \\
\text { expectations, managing the team within in terms of } \\
\text { the overall quality management, and developing staff } \\
\text { in recruitment and training [39]. }\end{array}$ & $\begin{array}{l}\text { Project description and contractual } \\
\text { arrangement, quality performance } \\
\text { attributes such as quality } \\
\text { definition awareness and ranking } \\
\text { of consequences of quality failures }\end{array}$ \\
\hline $\begin{array}{l}\text { Q 16-19, CMs: Ranking } \\
\text { and Multiple Choice } \\
\text { Statistical Test: Pearson's } \\
\text { Chi Squared, Relative } \\
\text { Importance Index }\end{array}$ & $\begin{array}{l}\text { Technical role delegation with constructability and } \\
\text { value-engineering experience to coordinate the } \\
\text { material resources, machinery, and manpower to } \\
\text { execute the project under the agreed-upon schedule } \\
\text { [40]. This overlaps with the role of the SM in } \\
\text { administering erosion and sediment control, } \\
\text { storm-water, construction air quality plans, } \\
\text { and construction site air quality plans [41-43]. }\end{array}$ & $\begin{array}{l}\text { Quality performance attributes, } \\
\text { such as quality definition } \\
\text { awareness and ranking of } \\
\text { consequences of quality failures. }\end{array}$ \\
\hline $\begin{array}{l}\text { Q 20-29 QMs: } \\
\text { Ranking, Likert, } \\
\text { and Multiple Choice } \\
\text { Statistical Test: Pearson's } \\
\text { Chi Squared, Relative } \\
\text { Importance Index, } \\
\text { Cronbach Alpha, U test }\end{array}$ & $\begin{array}{l}\text { Inspection and testing required to verify that the } \\
\text { activities executed are code complaint, conforming to } \\
\text { project specifications. Handles discrepancies in } \\
\text { designs, construction drawings, and rules on any } \\
\text { non-conformances occurring on-site against } \\
\text { standards and specifications. Role overlaps with that } \\
\text { of the SM in the commissioning process to ensure all } \\
\text { energy- and water-related building components are } \\
\text { fully functioning before handover [44]. }\end{array}$ & $\begin{array}{l}\text { Quality performance attributes, } \\
\text { such as quality definition } \\
\text { awareness, consequence ranks, } \\
\text { complexity levels for costing } \\
\text { quality activities, project period } \\
\text { commissioning scope formula, } \\
\text { which is fully defined. }\end{array}$ \\
\hline $\begin{array}{l}\text { Q 30-39 SMs: } \\
\text { Likert, Multiple Choice }\end{array}$ & $\begin{array}{l}\text { Project-team stewardship required to ensure } \\
\text { sustainability traits of the project are prioritized, } \\
\text { and the project is audited in terms of sustainability } \\
\text { points and credits that the project team are } \\
\text { committed to. Rules out any non-conformance } \\
\text { occurring on-site against sustainability requirements. } \\
\text { Takes a leading role in coordinating advanced } \\
\text { commissioning processes for the multiple mechanical } \\
\text { and electrical building components }[45,46] \text {. }\end{array}$ & $\begin{array}{l}\text { Type of green certification } \\
\text { pursued, determining if } \\
\text { sustainability is embedded in } \\
\text { quality KPIs; potential } \\
\text { denunciations of sustainability } \\
\text { credits and types of corrective } \\
\text { actions that occur in event of } \\
\text { sustainability non-conformance. }\end{array}$ \\
\hline $\begin{array}{l}\text { Q 40-49 FMs } \\
\text { Likert, Multiple Choice } \\
\text { Statistical Test: Pearson's } \\
\text { Chi Squared, Relative } \\
\text { Importance Index, } \\
\text { Cronbach Alpha, U test }\end{array}$ & $\begin{array}{l}\text { Functionality of the building facility by ensuring } \\
\text { end-user safety and satisfaction, maintaining the } \\
\text { building facility, and sustaining profitability for the } \\
\text { owners [47]. Conducts regular commissioning to } \\
\text { improve building operations and energy and } \\
\text { resource efficiency. }\end{array}$ & $\begin{array}{l}\text { Project description, complexity } \\
\text { level in costing quality activities, } \\
\text { and liaison of operations with } \\
\text { design and construction. }\end{array}$ \\
\hline
\end{tabular}

\subsection{Questionnaire Distribution Process}

The potential respondents were chosen using a purposive sampling approach to determine the participants who have the reputation of being involved in green-building projects and would be interested in being involved in research studies [48,49]. Ling and Gui (2009) indicated that professionals and managers in the construction industry exhibit a general reluctance regarding participation in research and recommended this method to mitigate this problem [50]. Local green-building councils and professional engineering institutions were approached and briefed on the research objectives 
to provide suitable contacts, and the potential interviewee was informed beforehand about the recommendation. Furthermore, the researchers visited governmental institutions that were client stakeholders of green-building projects and who were asked to contact consultants and contractors of the project. The selection criteria for the participants are: (1) they have a green certification accreditation; (2) they are currently or have worked in a green building project; (3) they are working for major construction organizations including owner representatives, consultants, and main contractors.

Subsequently, the survey was sent to the practitioners with SurveyMonkey and an introductory email and certification from the institutional review board. The total of 120 respondents were approached from which a turnover of 96 responses attained with 64 completed responses. Demographics of the respondents in terms of managerial type, entity representing, green building project type involved in are shown in the Section 3.

\subsection{Questionnaire Reliability and Validity}

A preliminary survey was presented to 2 professionals of almost 15 years of quality management experience in green buildings to appraise the questions on ranking of quality consequences and the quality activities chosen (Q20-29 which were repeated also for Construction Managers, Facility Managers, and Project Managers). The professionals agreed on the questions mentioned and added two more items for measuring complexity level in costing quality activities: "Power surges affecting building management system from software glitches causing the water systems' cistern malfunction" and "6 month chemical and bacterial tests for drinking water supplies". In addition, an application to the Institutional Review Board (IRB) was submitted to ensure that the questions in the survey comply with the local codes of conduct and ethics as well as ensuring the respondents' profiles and companies remained confidential.

Statistical techniques were used to ensure reliability and validity of the questionnaire results collected in the study. Reliability tests such as Cronbach's Alpha $(\alpha)$ were used to test the internal consistency of the Likert measures for the complexity of measuring the cost of quality activities and correlations were determined using Pearson's chi-squared $\left(\mathrm{X}^{2}\right)$ tests and Student's T-tests. Finally, Mann-Whitney U-test was done as an extra verification for the results on Section 3.2.

\section{Results}

The different managerial types are shown in Figure 2. The SMs were the most responsive, probably owing to their apparent dedication to sustainability and the green-building delivery process.

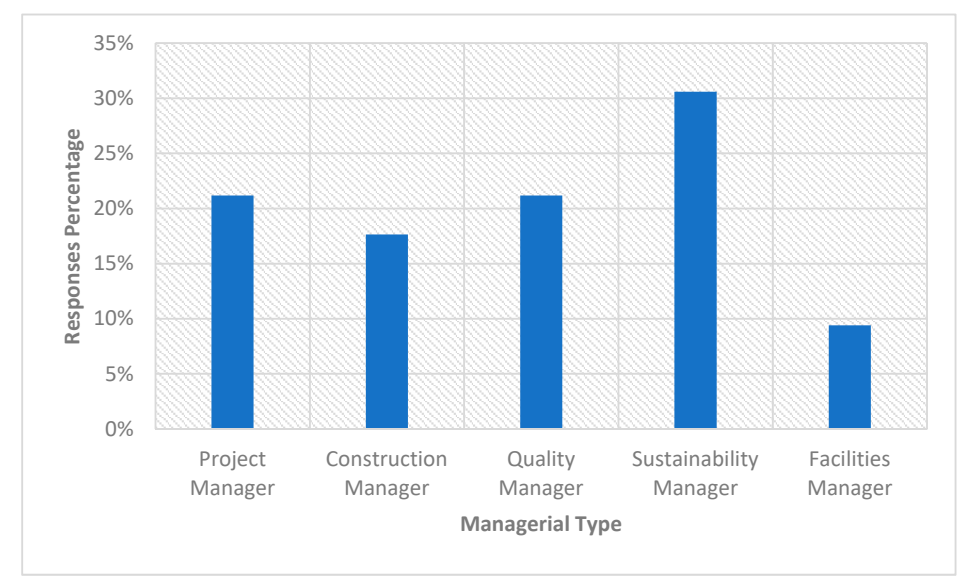

Figure 2. Types of managerial practitioners.

Figure 3 analyzes the firms, thereby presenting 32\% contractor representation, 30\% client representation, and 33\% consultant representation. The years of experience of the managers vary, as shown in in Figure 4. This clearly indicates the relative newness of the green-building industry, 
given the significant proportion of fewer years of green-building experience compared to that of conventional-project experience. The portfolio of green-building projects in Figure 5 presents predominantly commercial $(30 \%)$ and sports complexes $(22 \%)$ projects. The remaining $48 \%$ are residential, schools/universities, healthcare, and offices.
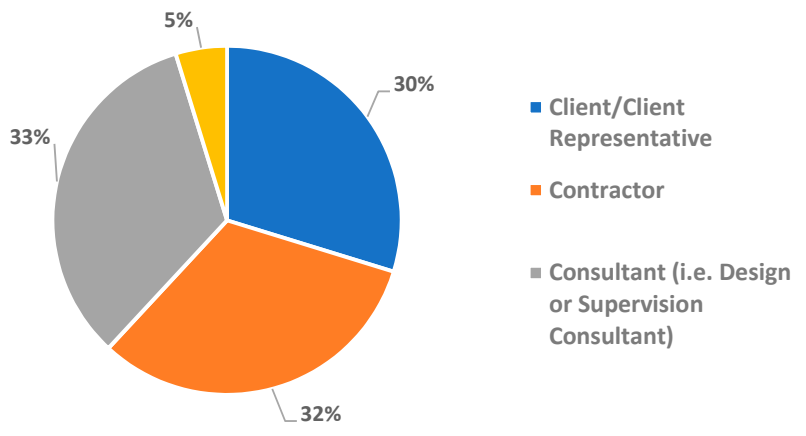

Figure 3. Entities represented by managers.

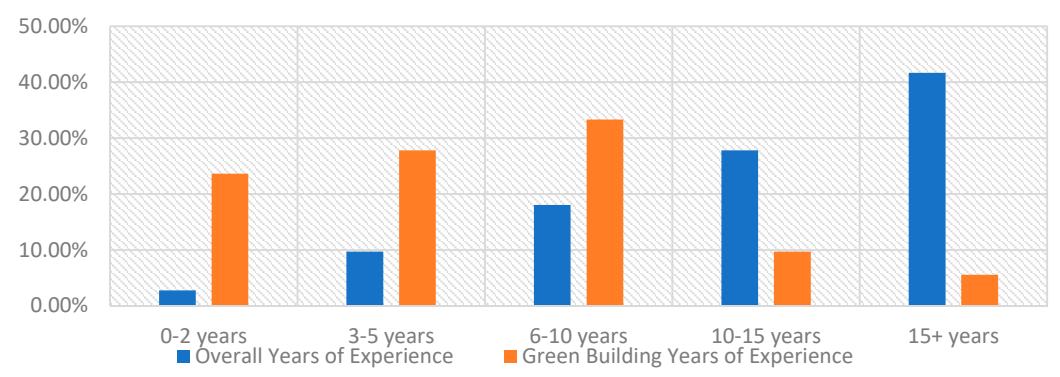

Figure 4. Managers' years of experience.

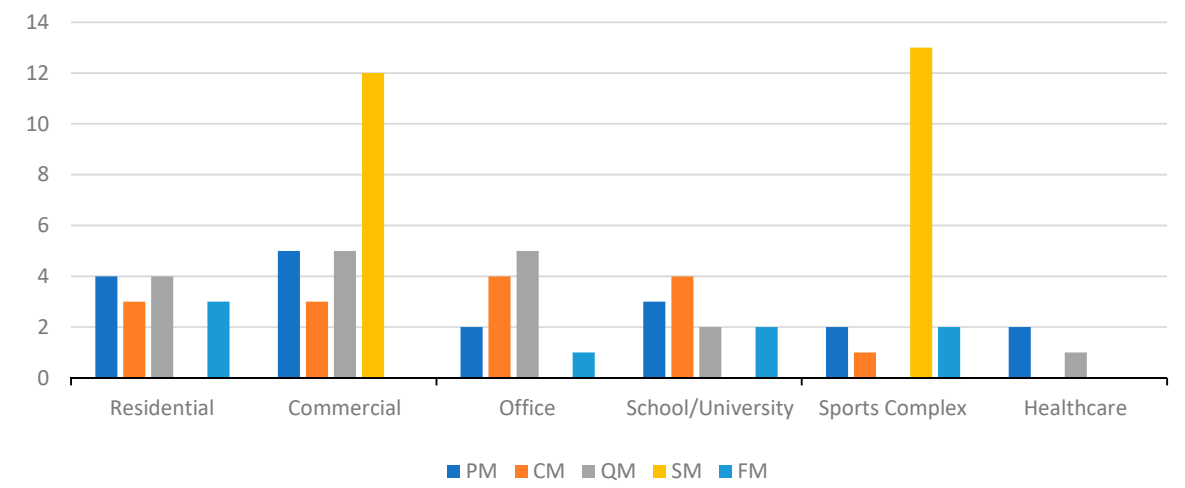

Figure 5. Green-building types and involved managers.

\subsection{Awareness of Quality Control and Assurance}

Quality control and assurance are two important mechanisms in quality performance domain and are distinguished based on the stakeholder party role covering for the mechanisms (quality assurance by the owner representative and quality control by the design or construction professional). To determine the respondents' awareness of the quality assurance and quality control $(\mathrm{QA} / \mathrm{QC})$, the respondents were asked to match the $\mathrm{QA} / \mathrm{QC}$ to its correct definition [51]. Figure 6 depicts the overall rate of correct responses across the various managerial types with respect to the total number of respondents with rates of $50-53 \%$ of correct definitions:

Pearson's chi-squared $\left(X^{2}\right)$ test was conducted to determine whether the managerial type influenced the correct answer response rate of the QA/QC definitions with a null hypothesis that there was no difference between the various managerial types' awareness on quality assurance and control definitions. There was a statistically weak evidence against the null hypothesis of difference in 
managerial types ( $p$-value of 0.977 at $5 \%$ significance). Thus, there was no predominant managerial group with better awareness on the responsible stakeholder for quality control and quality assurance.

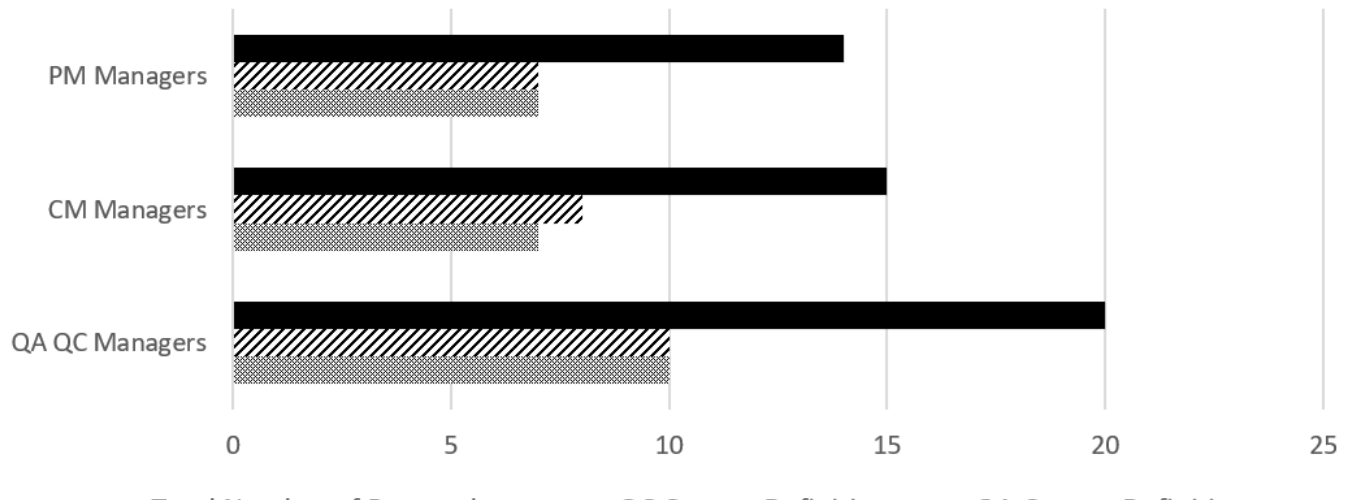

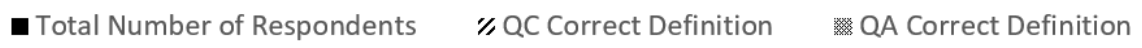

Figure 6. Correct responses regarding quality assurance and quality control (QA/QC) definition.

\subsection{Ranking of Quality Consequences}

Seyis et al. (2016) reported defects, revisions, and rework to be the main waste types during the design and construction stages [52]. Based on this premise and interviews with managerial practitioners in the pilot study stage, eight quality failure consequences were inferred (Figure 7).

Table 2. Quality Failure Types.

\begin{tabular}{cl}
\hline Reference & \multicolumn{1}{c}{ Quality Failure Definition } \\
\hline$[53,54]$ & $\begin{array}{l}\text { Liquidated damages: owner recovers delay costs caused by the contractor. The recovery can also } \\
\text { be apportioned among the parties when the delay is concurrently caused. }\end{array}$ \\
{$[18,55]$} & $\begin{array}{l}\text { Cost overuns in rectifying mistakes: cost increases over the original contract value owing to } \\
\text { rectifications of non-conformances during design and construction. }\end{array}$ \\
{$[56,57]$} & $\begin{array}{l}\text { Material loss: replacing defected products or quantities that deviate from what was stipulated in } \\
\text { the design. }\end{array}$ \\
{$[56]$} & $\begin{array}{l}\text { Labour productivity loss: human activity that does not generate value, caused by rectifying } \\
\text { mistakes. }\end{array}$ \\
{$[58,59]$} & $\begin{array}{l}\text { Assigning team to work overtime: assignment to work extra hours to meet a compressed } \\
\text { schedule and compensation for repaired defects. }\end{array}$ \\
{$[60]$} & $\begin{array}{l}\text { Schedule delays: project takes longer to complete because of rectifications of design/construction } \\
\text { mistakes or higher required quality expectations. } \\
\text { Reputation loss: firm loses reputation of competence because of defect compliance, which affects } \\
\text { future bids. }\end{array}$ \\
\hline 6
\end{tabular}

The three managerial types targeted for this question were the PMs, CMs, and QMs. The respondents were asked to rank the seven consequences of quality identified in literature based on their managerial purviews. Rank 1 represents the top consequence, which their managerial periphery influenced, and Rank 7 represents the least consequence.

The relative importance index (RII) was used to rank the consequences on a range of $0-1$ with Equation (1):

$$
\mathrm{RII}=\sum \frac{\mathrm{W}_{\mathrm{i}}}{\mathrm{A} \times \mathrm{N}^{\prime}}
$$

where $W_{i}$ is the weighted sum. The equation depends on an opposing scale of ranks, therefore the interpretation was done in reverse order. Table 3 shows the results.

The QMs ranked Cost Overruns in Rectifying Mistakes, Reputation Loss, and Schedule Delays as the top-three consequences on which they had an influence, whereas the PMs ranked Cost Overruns in Rectifying Mistakes, Schedule Delays, and Reputation loss as the top-three consequences on which 
they had an influence upon. The CMs ranked Schedule Delays, Material Loss, and Labor Productivity Loss as the top-three consequences on which they had an influence.

Table 3. Relative importance index of various failure consequences ranked by various managerial types.

\begin{tabular}{lcccccc}
\hline \multicolumn{1}{c}{ Managerial Type } & \multicolumn{2}{c}{ QMs } & \multicolumn{2}{c}{ PMs } & \multicolumn{2}{c}{ CMs } \\
\hline & RII & Rank & RII & Rank & RII & Rank \\
\hline Liquidated Damages & 0.7273 & 6 & 0.6364 & 5 & 0.7347 & 6 \\
Reputation Loss & 0.4156 & 2 & 0.4805 & 3 & 0.7551 & 7 \\
Cost Overruns in Rectifying Mistakes & 0.3377 & 1 & 0.4026 & 1 & 0.5714 & 4 \\
Schedule Delays & 0.5455 & 3 & 0.4156 & 2 & 0.3061 & 1 \\
Material Loss & 0.6494 & 5 & 0.6494 & 6 & 0.4796 & 2 \\
Labor Productivity Loss & 0.5974 & 4 & 0.6234 & 4 & 0.5204 & 3 \\
Assigning Team to Work Overtime & 0.7273 & 6 & 0.7403 & 7 & 0.6327 & 5 \\
\hline
\end{tabular}

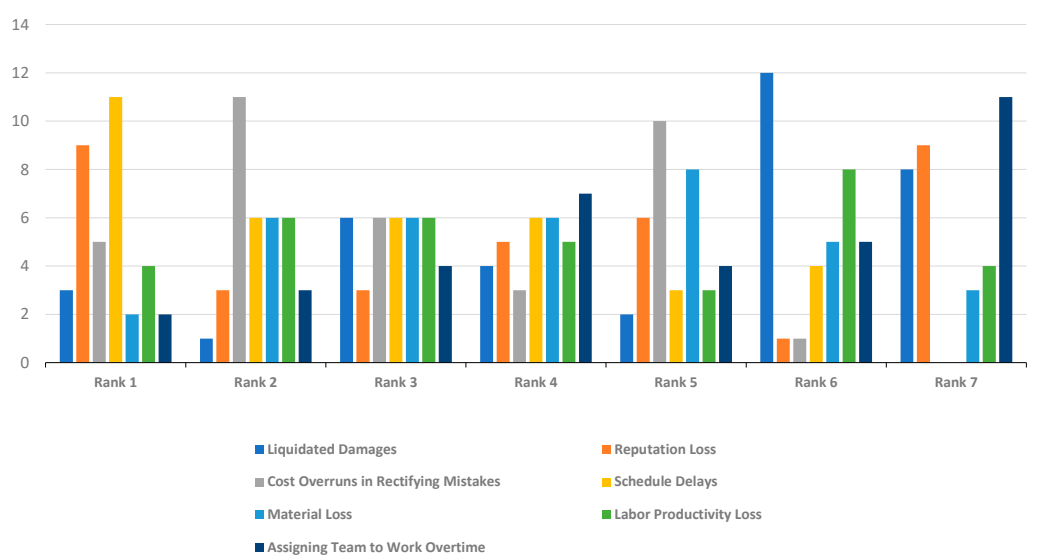

Figure 7. Managerial responses to consequence priorities.

The factor of schedule delays was ranked lower by QMs because they establish hold points that halt subsequent construction phases and conduct verifications to check that a certain construction task follows the standards. However, Labor Productivity Loss linked to CMs in their perception of their influence on the Labor Productivity Loss quality consequence. One QM highlighted the impact of executing rework; in his or her experience, non-conformance had undermined labor's morale because the executed work was ultimately aborted. Although, studies have indicated that Overtime and Labor Productivity were inversely correlated [58,59,62], PMs and CMs did not consider Overtime as important as Labor Productivity, which may be significantly influenced by their responsibilities for upholding the consequences of delays. Moreover, Liquidated Damages was expected to be highly ranked which was not the case. This may be because of the current lack of legislations present for green buildings that other countries (such as the United States) has for their green certifications [63]. Legislation measures can include a performance bond to ensure the building operates as per what it was designed for.

The QMs considered that Reputation Loss had a higher priority, because it was embedded in their work philosophy based on the consequences on the perceived integrity of their firm. The CMs did not perceive Reputation Loss as more important than the QMs and PMs because of their perception that their purview had a stronger influence on overcoming consequences of work completion and cost overruns when rectifying mistakes. This may be attributed to the $\mathrm{CMs}^{\prime}$ greater technical competence regarding the use of construction knowledge and practices during execution to achieve the overall objectives. In addition, it may be attributed to value engineering (i.e., achieving a functional performance at a lower cost), which is required to overcome cost and schedule challenges.

An unexpected result was the low ranking for Material Losses as a consequence that the PMs and QMs could influence. Green buildings produce less construction and demolition waste because of 
the construction waste management plans implemented [64,65]. Thus, it was expected that managers would rank Material Loss higher. Formoso et al. (2002) argued that managerial improvements were instrumental for reducing waste, particularly during the early stages of modular design coordination and integration of building systems [56]. Moreover, Formoso et al. (2002) reported that component specifications must be sufficiently detailed to support the efficacy of the procured materials and proposed that if "Construction Waste Management" was considered as a KPI in the same way as the cost and schedule, more construction and demotion waste reduction could be value-engineered by the CMs [56].

Tam et al. (2005) championed prefabrication as a construction method to reduce material waste [66]. However, a CM mentioned that they worked in a green prefabricated building project with no waste control. The building components were premanufactured overseas, and the QA/QC were controlled at a different geographic location. In addition, the $\mathrm{CM}$ explained that the dimensions of certain types of steel chassis were incorrect and no longer feasible. If the fabrication company had preassembled a built facility, there would be negligible losses. The inadequacies and inaccuracies of building information communicated between fabrication plants and building sites were driving factors for Zhong et al. (2017) to leverage the communication technology (i.e., Internet of Things) to streamline collaborations and promote synergy between geographically separated locations [67].

In this study, the results were analyzed with the Mann-Whitney U-test to determine whether the different managerial groups possessed different ranking perceptions. The test was a nonparametric statistical test applicable to ordinal data; no normal distribution was assumed, and the sample group sizes could be different [68]. Three groups were identified: QMs, PMs, and CMs, which resulted in a total of six tests per group combination similar to a method adopted in [69] and is based on the following two hypotheses:

$\mathbf{H}_{0}$ : Null hypothesis: there is no difference between the groups; thus, they possess the same mean $\left(H_{0}: P M=\right.$ $C M=Q M)$.

$\mathbf{H}_{1}$ : Alternate hypothesis: there is a difference between the groups; thus, there exists three different means $\left(H_{1}\right.$ : $P M \neq C M \neq Q M)$.

Table 4 presents the p-value results with those below 0.05 indicate the rejection of the null hypothesis. All consequences of Test 2 (PMs and QMs) exhibited significant statistical differences in the rankings, whereas those of Test 1 (PMs and CMs) and Test 3 (QMs and CMs) exhibited significance for Liquidated Damages, Schedule Delays, Labor Productivity Loss, and Overtime for Test 1 and Liquidated Damages, Labor Productivity Loss, and Overtime for Test 2 . The results reflect the differences between the different managerial types and validate the differences in perceptions of the consequences from the rankings conducted. The nuances of the different managerial types in evaluating quality failure consequences can be concluded to differ between the types.

Table 4. Mann-Whitney U-Test results for cross-comparing managerial types and quality failure consequences. A over or below 0.05 .

\begin{tabular}{cccc}
\hline \multirow{2}{*}{$\begin{array}{c}\text { Quality Failure Consequences Ranked } \\
\text { in Terms of Managerial-Type Influence }\end{array}$} & \multicolumn{2}{c}{ Asymptotic Significance (Two-Tailed) of Pairwise Comparison } \\
\cline { 2 - 3 } & PMs $\mathbf{1}$ & Test 2 & Test 3 \\
\cline { 2 - 3 } & 0.3443 & PMs and QMs & QMs and CMs \\
\hline Liquidated Damages & 0.0209 & 0.440 & 0.8234 \\
Reputation Loss & 0.040 & 0.542 & 0.0133 \\
Cost Overruns & 0.242 & 0.315 & 0.0128 \\
Schedule Delays & 0.0817 & 0.230 & 0.0201 \\
Material Loss & 0.456 & 0.8128 & 0.0973 \\
Labor Productivity Loss & 0.306 & 0.8145 & 0.5075 \\
Overtime & & 0.8658 & 0.4045 \\
\hline
\end{tabular}




\subsection{Complexity in Evaluating Quality Performance}

To test the extent to which the QMs and FMs were capable of readily costing preventative, appraisal, or rework actions, a series of items was presented with a six-point Likert scale to evaluate each item in terms of its level of complexity. The scale ranged from Very Simple (1) to Not Feasible (6). The questions were derived from green-building projects' quality plans, commissioning plans $[44,45,70]$, and studies based on the CoQ [23-25]. The included quality activity items were costs accounted with rectifying non-conformance through construction rework (item 1); costs accounted with rectifying non-conformance through design rework (item 2); total cost for QA/QC personnel for a specific task (i.e., activity-based costing) (item 3); inspection costs for extra low voltage systems (e.g., HVAC and lighting control) (item 4); revising design drawings to achieve code compliance before issuing issue for construction designs (item 5); testing and balancing of water systems (item 6); factory tests for high voltage switchgears (item 7); repair of green-building technology defects after handover (e.g., HVAC/greywater system/rainwater system) (item 8); indoor humidity and mold growth from ventilation (item 9); installation errors from inexperienced sub-contractors (item 10); and power surges affecting software glitches for building automation systems causing water systems' cistern malfunction (item 11). The internal consistency of the questions helped ensure that the overall complexity was reflected when evaluating the quality performance with Cronbach's Alpha $(\alpha)$ : $\alpha$ ranged from 0 to 1 , and the higher values indicated a greater internal consistency and (ultimately) reliability. The results exhibited a value of 0.745 , which indicates a fair consistency. This represents the complexity level in the quality performance evaluation. The complexities of various items are presented in Figure 8.

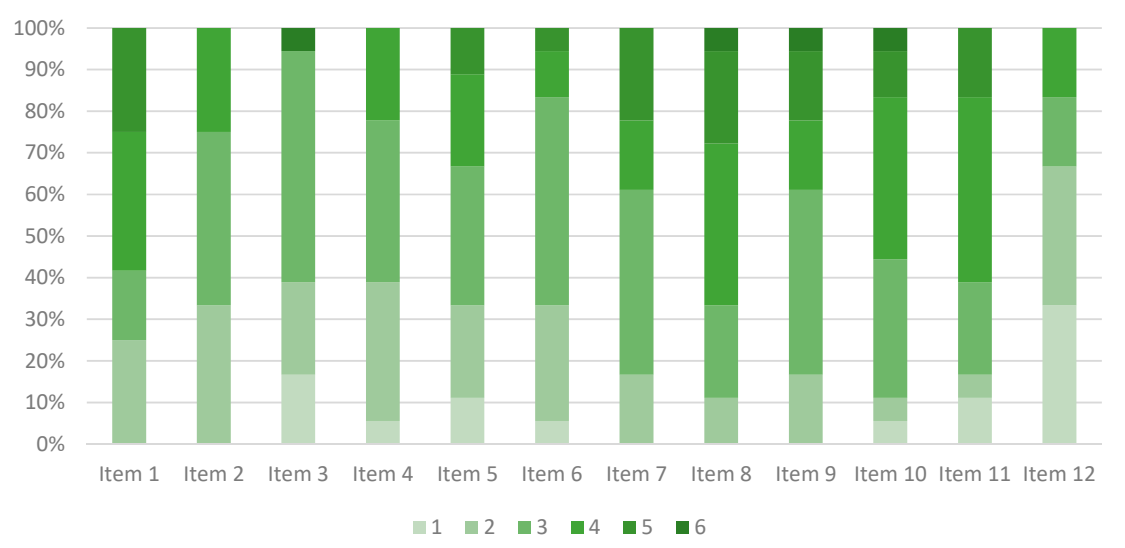

Figure 8. Quality activity items and complexity results (complexity level color coding is explained in the legend).

A Student's T-test was conducted for the first objective to determine if the quality activities in the design, construction, and operation stages were considered too complex to cost and derive the differences among the CMs and operation-stage managers (depending on their perceptions of complexity). Only QMs and FMs were chosen for this task, because they were directly involved in $\mathrm{QA} / \mathrm{QC}$ activities during the construction and operational stages. The null hypothesis, $\mathrm{H}_{\mathrm{o}}$ is that the hypothesized mean for the level of complexity measured with the Likert scale was below 3 was tested with the Likert scale, where the hypothesized mean for the level of complexity was below 3 (i.e., from neutral to very simple). A $p$-value of below 0.05 implies that the null hypothesis is rejected, which is feasible if the level of complexity is greater than 3 (i.e., from complex to not feasible). Table 5 lists all $p$-values of the T-tests.

The results indicate that the conformance activities (preventative and appraisal) were usually less difficult to cost for both managerial types compared to non-conformance activities (rework). The rework activities were perceived as complex by both QMs and FMs, and the green-building-related 
rework (e.g., power surges affecting software glitches for building management systems and repairs of green-building technologies) had lower p-values, which indicates greater perceived complexities.

Table 5. Student's T-test results for level-of-complexity of various quality activities.

\begin{tabular}{|c|c|c|c|c|c|}
\hline \multirow[b]{2}{*}{ Type } & \multirow[b]{2}{*}{ Item Number } & \multicolumn{4}{|c|}{$\begin{array}{c}\text { Student's T Test for One Sample Mean } \\
\mathrm{H}_{\mathrm{o}}: \text { Hypothesized Mean for the Level of Complexity Is Below } 3\end{array}$} \\
\hline & & Item Description & Both Groups & QM Only & FM Only \\
\hline Rework & 1 & $\begin{array}{l}\text { Costs accounted with rectifying } \\
\text { non-conformance through } \\
\text { construction rework }\end{array}$ & NA & 0.0177 & NA \\
\hline Rework & 2 & $\begin{array}{l}\text { Costs accounted with rectifying } \\
\text { non-conformance through design } \\
\text { rework }\end{array}$ & NA & 0.376 & NA \\
\hline $\begin{array}{l}\text { Preventative } \\
\text { and Appraisal }\end{array}$ & 3 & $\begin{array}{l}\text { Total cost for QAQC personnel for } \\
\text { a specific task (activity-based } \\
\text { costing) }\end{array}$ & 0.174 & 0.5 & $0.003 *$ \\
\hline Appraisal & 4 & $\begin{array}{l}\text { Inspection costs for extra low } \\
\text { voltage Systems (HVAC and } \\
\text { lighting control) }\end{array}$ & 0.1646 & 0.217 & $0.042 *$ \\
\hline Preventative & 5 & $\begin{array}{l}\text { Revising design drawings to } \\
\text { achieve code compliance before } \\
\text { construction drawings }\end{array}$ & NA & 0.403 & NA \\
\hline Appraisal & 6 & $\begin{array}{l}\text { Testing and balancing of water } \\
\text { systems }\end{array}$ & 0.412 & 0.388 & 0.071 \\
\hline Appraisal & 7 & $\begin{array}{l}\text { Factory tests for high-voltage } \\
\text { switchgears }\end{array}$ & 0.412 & 0.2915 & 0.071 \\
\hline Rework & 8 & $\begin{array}{l}\text { Repair of green-building } \\
\text { technology defects after handover } \\
\text { (HVAC/greywater } \\
\text { system/rainwater system) }\end{array}$ & 0.0000128 & 0.00093 & 0.5 \\
\hline Rework & 9 & $\begin{array}{l}\text { Indoor humidity and mold } \\
\text { growth from ventilation }\end{array}$ & 0.195 & 0.0177 & 0.187 \\
\hline Rework & 10 & $\begin{array}{l}\text { Installation errors from } \\
\text { inexperienced sub-contractors }\end{array}$ & 0.0078 & 0.000133 & 0.2611 \\
\hline Rework & 11 & $\begin{array}{l}\text { Power surges affecting software } \\
\text { glitches for building automation } \\
\text { systems causing water systems' } \\
\text { cistern malfunction }\end{array}$ & 0.0143 & 0.00005 & 0.204 \\
\hline Appraisal & 12 & $\begin{array}{l}\text { 6-month chemical and bacterial } \\
\text { test of drinking-water systems }\end{array}$ & NA & NA & 0.241 \\
\hline Rework & 13 & $\begin{array}{l}\text { Plumbing Defects: Water } \\
\text { Hammer, Back-Siphonage }\end{array}$ & NA & NA & 0.229 \\
\hline
\end{tabular}

The results show that the design rework was considered simpler to cost compared to construction rework, which is an encouraging statistic for the importance of adequate design reviews as opposed to rushing into construction and facing lengthy complexities. Newton and Christian (2006) investigated how quality affects life cycle costs and highlighted that design quality had the greatest impact on the maintenance and rehabilitation costs [71].

\subsection{Sustainability and Quality: Relationships and Performances}

In this study, it was determined whether the quality performance and sustainability traits were correlated by asking the SMs if the KPIs of the quality performance were affected by sustainability traits. The results in Figure 9indicate a strong skew towards a correlation of the sustainability traits in material submittals, non-conformance reports, and inspection requests, which confirms that the sustainability is directly connected with the quality performance of green buildings. This reinforces the notion that the quality-performance domain is crucial for successfully delivering green buildings. The QMs were asked whether they considered the quality KPIs to be more challenging in a green building than in a conventional building. The results in Figure 10 reveal a higher difficulty $(50 \%)$ or the same difficulty (50\%). However, no manager stated that meeting the KPIs of green buildings was 
easier than for conventional buildings. This may be attributed to limited types of energy efficient materials and technology types being available within proximity in the market [52].

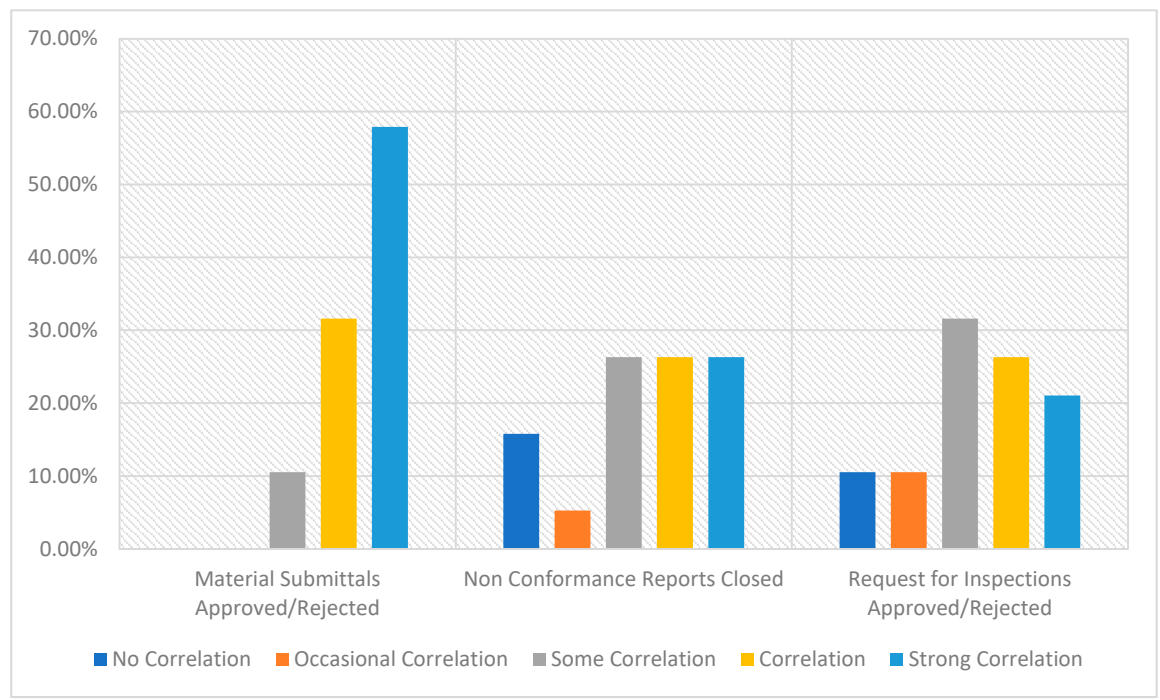

Figure 9. Correlation extent of sustainability traits of various quality key performance indicators (KPIs).

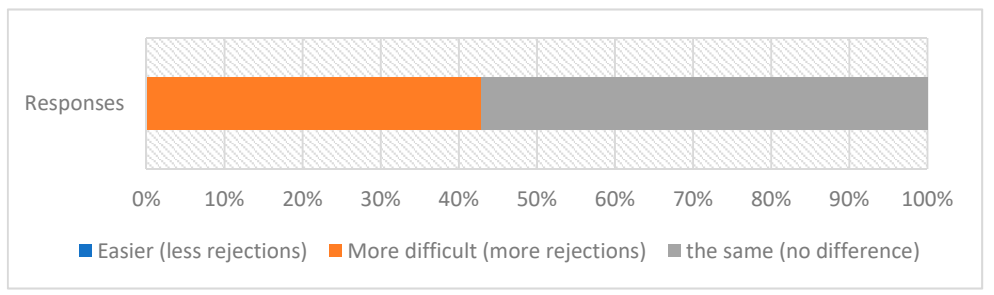

Figure 10. Responses of impact of sustainability traits on meeting quality KPIs.

The SMs found that non-conformance related to sustainability was more likely to be rectified as a design rework rather than as a construction rework, as shown in Figure 11. This may be attributed to the substantial $43 \%$ of respondents claiming to have endured management dismissing certain sustainability credits for no longer being obliged to achieve them (such design omissions being found to be a root cause for design reworks according to Love, et al. [72]). In addition, according to Figure 11, $63 \%$ of respondents endured this type of credit dismissal because of budget limitations and 13\% because of schedule compression. This could have been avoided if CMs had been involved in the design stages to give constructability feedback before the full dedication to such green-building credits.

Commissioning is a delivery phase that ensures that the building performs properly, efficiently (according to sustainability metrics), code-compliantly, and cost-effectively during maintenance [73]. Reed and Gordon (2000) asserted that the significance of commissioning green buildings should not be compromised because of their complexity [74]. Commissioning processes ideally commence early during the pre-design stage to ensure the useful formulation of the project requirements [74]. This, in turn, is used as the basis of devising mechanisms required to assure building quality.

The QMs were asked certain questions to determine the phase at which the commissioning scope definition commences in a project and when it should be fully defined. Contrary to expectations, the results of Figure 12 imply that most respondents (50\%) indicated that the commissioning scope begins at the construction stage. This explains why $50 \%$ of the respondents indicated that the full definition of commissioning is established during the testing and commissioning stages. Another expectation was that the scope would be fully defined earlier than the testing and commissioning stages to ensure fewer upcoming unknown requirements in the project. The results defied the recommendations of Robichaud and Anantatmula (2011) [75], who wanted to ensure that the cross-discipline interaction 
occurred at the earliest stage of the project to ensure financial success. O'Connor et al. (2016) advocated for commissioning during the design phase to provide the team with more knowledge of how the systems should be handled and tested and to obtain the far-reaching benefits of discovering issues up front, potentially by yielding cost savings [76]. Green certification systems need to apply measures to protect against late commissioning commencement especially as the commissioning entity will have an overall lifecycle periphery and can contribute in providing an extra verification that the sustainability requirements are embedded in the design in a manner that is constructible and operable. Enabling commissioning can influence the managerial perspectives towards quality performance because it holds the contractors and owners more accountable on the project goals whether these are sustainability traits [77].

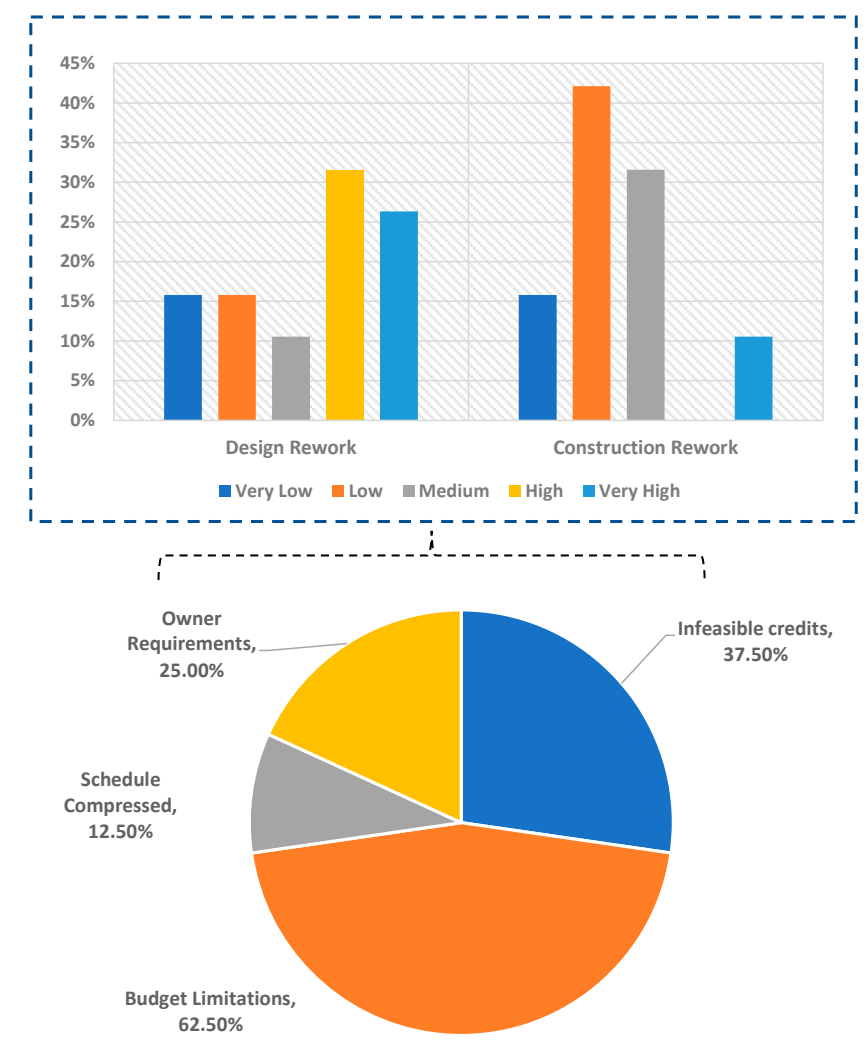

Figure 11. Likelihood of rework types caused by sustainability non-conformance. 


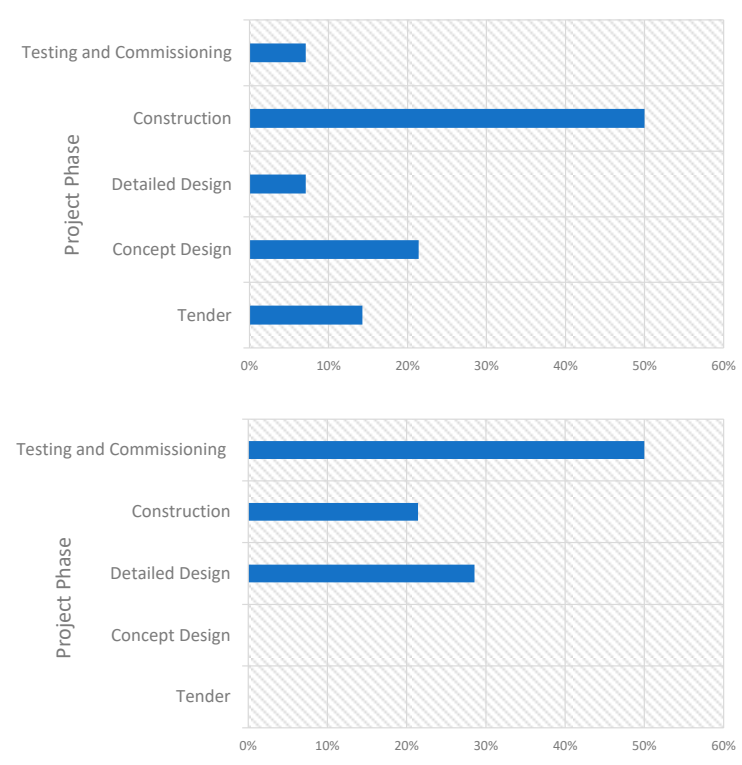

Figure 12. Response on commissioning scope commencement (top) and commissioning scope finalization (bottom).

\section{Conclusions}

Measuring the quality performance when executing a green-building project enables managers and stakeholders to determine the extent to which green buildings achieve code compliance and high-performance quality. This research study was conducted based on a questionnaire survey to investigate how the different manager types perceived the quality performance, and to study the extent to which their objectives regarding the quality performance were aligned. The results support the importance of quality performance in the green-building project management. Further, the construction industry must evaluate the quality performance meticulously, particularly when CoQ approaches are employed. This study was accomplished by first reviewing the quality, testing, and commissioning plans of green-building projects and by reviewing academic literature to identify the CoQ components. These activities provided the basis for producing a questionnaire survey focused on quality performance, with questions tailored to the different managerial types. Subsequently, the results were statistically analyzed to evaluate the data and to determine any underlying inferences based on the four given fields: QA/QC awareness; ranking of managerial purview influences on the various quality failure consequences; complexities in evaluating CoQ components; correlations between quality performance and sustainability traits. As technology advances, it may be possible to automate laborious $\mathrm{QA} / \mathrm{QC}$ processes [78].

The results highlight that the QA/QC awareness levels (the core mechanism of quality performance) of the various managerial types are not equitable. In addition, the prioritization of practitioners' purviews and their influences on preventing quality consequences are different. Whereas previous studies have adopted the $\mathrm{CoQ}$ to quantify quality performance, the results of this study consolidated the argument that the CoQ activities are too complex to justify financially. The authors plan to establish a more seamless and integrated approach to calculate the CoQ and deliver a project that covers the inception to operation simultaneously. As technology advances, it may be possible to automate laborious QA/QC processes [78], which will promote the integrated approach required for green-building project management $[75,79,80]$. The revelation of the embedded sustainability traits in the quality KPIs and the consequences of sustainability non-conformance can be used as an inference to rationalize high-cost overruns in green-building projects [33,34,81-84]. The study also highlighted the challenges faced by SMs to uphold commitment regarding design rework, in which enabling credits are often discouraged. A revelation that liquidated damages as a quality consequence was not as prioritized as other consequences and it may be because of the lack of legislative measures to bind the 
contractor to a performance bond. This would impact the tendency to revert to a design rework that may compromise sustainability traits of the project.

This study was faced with limitations because the authors aimed to investigate the latent effects of contractual traits (i.e., project delivery system type, procurement method, and payment provision) to determine how these traits affected quality performance. Love et al. (2018) revisited the study of Barber et al. (2000) of the quality failure costs falling upon the contractors "only if the client had identified the need for correction or the contractor was in a position to claim additional payments from the client related to extra work or against one of their subcontractors or suppliers." [17,85], thus the dynamics between the multiple parties would play an important role in quality performance [86-88]. The responses provided in the survey did not include sufficient response variety in the project delivery systems for deducing correlations. Furthermore, on many occasions, the more experienced managers had difficulty answering questions on single green-building projects, because of many prior projects that could have distorted the responses. The authors rarely received responses regarding a particular project from all managerial types. This was because of the high turnover rate, and because different managers were present in the prior design phases. A final limitation to mention is the current geopolitical climate in Qatar caused by the blockade which can limit certain green building materials [89], which may have influenced the managerial responses.

The results of this study contribute to academia, industry, and policy regarding green-building development and provide insight on how the different managerial practitioners perceive their purviews to influence the consequences of quality failures. Reworks is a pervasive issue in the construction industry with green buildings' sustainability characteristics can lead to more reworks vulnerability with cost overrun implications [52,90]. There is already an upfront cost investment for embarking in a green building and having cost overruns can deter owners from committing to green buildings. Holistically, the drive to promote sustainability practices across the construction industry may be hindered without a careful scrutiny on the intricacies that play on a micro building level role from the various managerial types. The managerial implications on quality performance in particular has an overarching effect on achieving the sustainability expectations which will requires more diligence on ensuring the upfront cost is well invested through an improved quality performance practice. For this reason, the study revealed the need for more efficient approaches for appraising quality performance, which will require decision makers to be critical of the procedures and promulgate better strategies to enhance measuring quality performance with more rigor in order to minimize associated cost overruns associated with consequential rework from poor quality. This will help governments gain more confidence in policies supporting the green building movement in its pursuit for sustainability in the industry $[91,92]$.

Supplementary Materials: The following are available online at http://www.mdpi.com/2075-5309/10/4/71/s1, with Supplementary Document containing the full statistical inferencing, Institutional Review Board (IRB) approval.

Author Contributions: A.M.R. designed the study and wrote the manuscript; S.G.A.-G. supervised the work reviewed and approved the final manuscript. All authors have read and agreed to the published version of the manuscript.

Funding: This research was supported by a scholarship (210004793) from Hamad Bin Khalifa University (HBKU) a member of Qatar Foundation (QF). Any opinions, findings, and conclusions or recommendations expressed in this material are those of the author(s) and do not necessarily reflect the views of HBKU or QF.

Conflicts of Interest: The authors declare no conflict of interest.

\section{References}

1. Fan, K.; Chan, E.H.W.; Chau, C.K. Costs and Benefits of Implementing Green Building Economic Incentives: Case Study of a Gross Floor Area Concession Scheme in Hong Kong. Sustainability 2018, 10, 2814. [CrossRef]

2. Fan, K.; Chan, E.; Qian, Q. Transaction costs (TCs) in green building (GB) incentive schemes: Gross Floor Area (GFA) Concession Scheme in Hong Kong. Energy Policy 2018, 119, 563-573. [CrossRef] 
3. Olanipekun, A.; Xia, B.; Hon, C.; Darko, A. Effect of Motivation and Owner Commitment on the Delivery Performance of Green Building Projects. J. Manag. Eng. 2018, 34, 04017039. [CrossRef]

4. Kubba, S. Green Project Commissioning. In Handbook of Green Bulding Design and Construction LEED, BREEAM, and Green Globes; Butterworth-Heinemann: Oxford, UK, 2017.

5. Newsham, G.R.; Mancini, S.; Birt, B.J. Do LEED-Certified Buildings Save Energy? Yes, But ... . Energy Build. 2009, 41, 897-905. [CrossRef]

6. Chokor, A.; El Asmar, M.; Tilton, C.; Srour, I. Dual Assessment Framework to Evaluate LEED-Certified Facilities Occupant Satisfaction and Energy Performance: Macro and Micro Approaches. J. Archit. Eng. 2016, 22, A4015003. [CrossRef]

7. Kern, A.P.; Antoniolli, C.B.; Wander, P.R.; Mancio, M.; Stumpf González, M.A. Energy and Water Consumption During the Post-Occupancy Phase and the Users' Perception of a Commercial Building Certified by Leadership in Energy and Environmental Design (LEED). J. Archit. Eng. 2016, 133, 826-834. [CrossRef]

8. Al Ghamdi, S.G.; Bilec, M. Green Building Rating Systems and Environmental Impacts of Energy Consumption from an International Perspective. In Proceedings of the International Conference on Sustainable Infrastructure, Long Beach, CA, USA, 6-8 November 2014; pp. 631-640. [CrossRef]

9. Altomonte, S.; Saadouni, S.; Kent, M.G.; Schiavon, S. Satisfaction with Indoor Environmental Quality in BREEAM and Non-BREEAM Certified Office Buildings. Archit. Sci. Rev. 2017, 60, 343-355. [CrossRef]

10. Coombs, K.; Vesper, S.; Green, B.J.; Yermakov, M.; Reponen, T. Fungal Microbiomes Associated with Green and Non-Green Building Materials. Int. Biodeterior. Biodegrad. 2017, 125, 251-257. [CrossRef]

11. Lu, W.; Chi, B.; Bao, Z.; Zetkulic, A. Evaluating the Effects of Green Building on Construction Waste Management: A Comparative Study of Three Green Building Rating Systems. Build. Environ. 2019, 155, 247-256. [CrossRef]

12. USGBC Research Committee. A National Green Building Research Agenda; US Green Building Council: New York, NY, USA, 2007.

13. Reeves, C.; Bednar, D. Defining Quality: Alternatives and Implications. Acad. Manag. Rev. 1994, 19, 419-445. [CrossRef]

14. Juran, J.M.; Gryna, F.M.; Bingham, R.S. Quality Qontrol Handbook; McGraw-Hill: New York, NY, USA, 1974.

15. Love, P. Influence of Project Type and Procurement Method on Rework Costs in Building Construction Projects. J. Constr. Eng. Manag. 2002, 128, 18-29. [CrossRef]

16. Jha, K.N.; Iyer, K.C. Critical Factors Affecting Quality Performance in Construction Projects. Total Qual. Manag. Bus. Excell. 2006, 17, 1155-1170. [CrossRef]

17. Love, P.; Teo, P.; Morrison, J. Revisiting Quality Failure Costs in Construction. J. Constr. Eng. Manag. 2018, 144, 05017020. [CrossRef]

18. Hwang, B.-G.; Thomas, S.R.; Haas, C.T.; Caldas, C.H. Measuring the Impact of Rework on Construction Cost Performance. J. Constr. Eng. Manag. 2009, 135, 187-198. [CrossRef]

19. Chiang, Y.H.; Li, V.J.; Zhou, L.; Wong, F.; Lam, P. Evaluating Sustainable Building-Maintenance Projects: Balancing Economic, Social, and Environmental Impacts in the Case of Hong Kong. J. Constr. Eng. 2016, 142, 06015003. [CrossRef]

20. Kamal, A.; Al-Ghamdi, S.G.; Koc, M. Building Stock Inertia and Impacts on Energy Consumption and CO2 Emissions in Qatar. In Proceedings of the ASME 2019 13th International Conference on Energy Sustainability collocated with the ASME 2019 Heat Transfer Summer Conference, Bellevue, WA, USA, 14-17 July 2019. [CrossRef]

21. Alborz, N.; Berardi, U. A Post Occupancy Evaluation Framework For LEED Certified U.S. Higher Education Residence Halls. Procedia Eng. 2015, 118, 19-27. [CrossRef]

22. Raouf, A.M.; Al-Ghamdi, S.G. Effect of R-Values Changes in the Baseline Codes: Embodied Energy and Environmental Life Cycle Impacts of Building Envelopes. Energy Rep. 2020, 6, 554-560. [CrossRef]

23. Abdelsalam, H.; Gad, M. Cost of Quality In Dubai: An Analytical Case Study Of Residential Construction Projects. Int. J. Proj. Manag. 2009, 27, 501-511. [CrossRef]

24. Heravi, G.; Jafari, A. Cost of Quality Evaluation in Mass-Housing Projects in Developing Countries. J. Constr. Eng. Manag. 2014, 140, 04014004. [CrossRef]

25. Kazaz, A.; Birgonul, T.; Ulubeyli, S. Cost-Based Analysis of Quality in Developing Countries: A Case Study of Building Projects. Build. Environ. 2005, 40, 1356-1365. [CrossRef] 
26. Raouf, A.; Al Ghamdi, S.G. The Effectiveness of Project Delivery Systems in Executing Green Buildings: A Review. J. Constr. Eng. Manag 2019. [CrossRef]

27. Korkmaz, S.; Riley, D.; Horman, M. Piloting Evaluation Metrics for Sustainable High-Performance Building Project Delivery. J. Constr. Eng. Manag. 2010, 136, 877-885. [CrossRef]

28. Raouf, A.; Al-Ghamdi, S.G. Building Information Modelling and Green Buildings: Challenges and Opportunities. Archit. Eng. Des. Manag. 2018. [CrossRef]

29. Lapinski, A.; Horman, M.; Riley, D. Lean Processes for Sustainable Project Delivery. J. Constr. Eng. Manag. 2006, 132, 1083-1091. [CrossRef]

30. Hwang, B.-G.; Shan, M.; Tan, E.K. Investigating Reworks in Green Building Construction Projects: Magnitude, Influential Factors, and Solutions. Int. J. Environ. Res. 2016, 10, 499-510.

31. Raouf, A.; Al-Ghamdi, S.G. Impact of Project Delivery Systems on Cost Overruns of Green Building Projects: System Dynamics Approach. In Proceedings of the International Conference on Sustainable Infrastructure 2019, Los Angeles, CA, USA, 6-9 November 2019; pp. 371-379. [CrossRef]

32. Raouf, A.M.; Al-Ghamdi, S.G. Framework to Optimize Cost of Quality in Delivering and Operating Green Buildings. In Proceedings of the International Conference on Sustainable Infrastructure 2019, Los Angeles, CA, USA, 6-9 November 2019; pp. 338-347. [CrossRef]

33. Isabelina, N.; Reichel, C. Adoption of High Performance Building Systems in Hot-Humid Climates-Lessons Learned. Constr. Innov. 2013, 13, 186-201. [CrossRef]

34. Hwang, B.G.; Leong, L.P. Comparison of Schedule Delay and Causal Factors between Traditional and Green Construction Projects. Technol. Econ. Dev. Econ. 2013, 19, 310-330. [CrossRef]

35. Jung, Y.; Sui, P.; Xi, H. Green Practices in The Chinese Building Industry: Drivers and Impediments. J. Technol. Manag. China 2012, 7, 50-63. [CrossRef]

36. Larsen, J.K.; Shen, G.Q.; Lindhard, S.M.; Brunoe, T.D. Factors Affecting Schedule Delay, Cost Overrun, and Quality Level in Public Construction Projects. J. Manag. Eng. 2016, 32, 04015032. [CrossRef]

37. Cohen, L.; Manion, L.; Morrison, K. Research Methods in Education; Routledge: New York, NY, USA, 2018.

38. Issa, M.H.; Rankin, J.H.; Christian, A.J. Canadian Practitioners' Perception Of Research Work Investigating The Cost Premiums, Long-Term Costs And Health and Productivity Benefits of Green Buildings. Build. Environ. 2010, 45, 1698-1711. [CrossRef]

39. Ceran, T.; Dorman, A.A. The Complete Project Manager. J. Archit. Eng. 1995, 1, 67-72. [CrossRef]

40. Jabar, I.1.; Ismail, F.; Aziz, N.M.; Janipha, N.A.I. Construction Manager's Competency in Managing the Construction Process of IBS Projects. Procedia Soc. Behav. Sci. 2013, 105, 85-93. [CrossRef]

41. US Green Building Council. LEED Reference Guide for Building Design and Construction; US Green Building Council: Washington, DC, USA, 2016.

42. BREEAM. BREEAM Communities Technical Manual. Available online: http://www.breeam.com/ communitiesmanual/content/00_introduction/03_introduction.htm (accessed on 29 May 2018).

43. Gulf Organisation for Research and Development. GSAS Technical Guide 2017; Gulf Organisation for Research and Development: Doha, Qatar, 2017.

44. Gulf Systems Contracting Company. Integrated Workers Accomodation Camp Plot 5 Quality Control Plan; Gulf Systems Contracting Company: Doha, Qatar, 2018.

45. Carillion. Technical Submittal of MEP Testing and Commissioning Plan for Musheireb Downtown Doha Phase $1 B$ Project; Carillion: Doha, Qatar, 2017.

46. AJB High Tech. Msheireb Downtown Doha Phase 3 Testing and Commissioning Plan; AJB High Tech: Doha, Qatar, 2017.

47. Shin, H.; Lee, H.-S.; Park, M.; Lee, J.G. Facility Management Process of an Office Building. J. Infrastruct. Syst. 2018, 24, 04018017. [CrossRef]

48. Palinkas, L.A.; Horwitz, S.M.; Green, C.A.; Wisdom, J.P.; Duan, N.; Hoagwood, K. Purposeful sampling for qualitative data collection and analysis in mixed method implementation research. Adm. Policy Ment. Health 2015, 42, 533-544. [CrossRef] [PubMed]

49. Patton, M. Qualitative Research and Evaluation Methods, 4th ed.; Sage Publications: California, CA, USA, 2015.

50. Ling, F.; Gui, Y. Strengths, Weaknesses, Opportunities, and Threats: Case Study of Consulting Firms in Shenzhen, China. J. Constr. Eng. Manag. 2009, 135, 628-636. [CrossRef]

51. ASCE. Quality Assurance and Quality Control. In Quality in the Constructed Project: A Guide for Owners, Designers and Constructors; American Society of Civil Engineers: Reston, VA, USA, 2012. 
52. Seyis, S.; Ergen, E.; Pizzi, E. Identification of Waste Types and Their Root Causes in Green-Building Project Delivery Process. J. Constr. Eng. Manag. 2016, 142, 04015059. [CrossRef]

53. Ibbs, W.; Nguyen, L.; Simonian, L. Concurrent Delays and Apportionment of Damages. J. Constr. Eng. Manag. 2011, 137, 119-126. [CrossRef]

54. Thomas, H.R.; Smith, G.R.; Cummings, D.J. Enforcement of Liquidated Damages. J. Constr. Eng. Manag. 1995, 121, 459-463. [CrossRef]

55. Forcada, N.; Gangolells, M.; Casals, M.; Macarulla, M. Factors Affecting Rework Costs in Construction. J. Constr. Eng. Manag. 2017, 143, 04017032. [CrossRef]

56. Formoso, C.T.; Soibelman, L.; Cesare, C.D.; Isatto, E.L. Material Waste in Building Industry: Main Causes and Prevention. J. Constr. Eng. Manag. 2002, 128, 316-325. [CrossRef]

57. John, A.O.; Itodo, D.E. Professionals Views of Material Wastage on Construction Sites and Cost Overruns. Organ. Technol. Manag. Constr. Int. J. 2013, 5, 747-757. [CrossRef]

58. Hanna, A.S.; Taylor, C.S.; Sullivan, K.T. Impact of Extended Overtime on Construction Labor Productivity. J. Constr. Eng. Manag. 2005, 131, 734-739. [CrossRef]

59. Alvanchi, A.; Lee, S.; AbouRizk, S. Dynamics of Working Hours in Construction. J. Constr. Eng. Manag. 2012, 138, 66-77. [CrossRef]

60. Kumaraswamy, M.M.; Chan, D.W.M. Contributors to Construction Delays. Constr. Manag. Econ. 1998, 16, 17-29. [CrossRef]

61. Akintoye, A.S.; MacLeod, M.J. Risk Analysis and Management in Construction. Int. J. Proj. Manag. 1997, 15, 31-38. [CrossRef]

62. Thomas, R. Effects of Scheduled Overtime on Labor Productivity. J. Constr. Eng. Manag. 1992, 118, 60-76. [CrossRef]

63. Seifert, B. District of Columbia Green Building Act of 2006 and Its Implications for Sureties. J. Prof. Issues Eng. Educ. Pract. 2008, 134, 84-86. [CrossRef]

64. Zuo, J.; Zhao, Z.-Y. Green Building Research-Current Status and Future Agenda: A Review. Renew. Sustain. Energy Rev. 2014, 30, 271-281. [CrossRef]

65. Yeheyis, M.; Hewage, K.; Alam, M.S.; Eskicioglu, C.; Sadiq, R. An Overview of Construction and Demolition Waste Management In Canada: A Lifecycle Analysis Approach to Sustainability. Clean Technol. Environ. Policy 2013, 15, 81-91. [CrossRef]

66. Tam, C.M.; Tam, V.W.Y.; Chan, J.K.W.; Ng, W.C.Y. Use of Prefabrication to Minimize Construction Waste-A Case Study Approach. Int. J. Constr. Manag. 2005, 5, 91-101. [CrossRef]

67. Zhong, R.; Peng, Y.; Xue, F.; Fang, J.; Zou, W.; Luo, H.; Thomas, N.; Lu, W.; Shen, G.; Huang, G. Prefabricated Construction Enabled By The Internet-Of-Things. Autom. Constr. 2017, 76, 59-70. [CrossRef]

68. Burke, R.; Parrish, K.; El Asmar, M. Environmental Product Declarations: Use in the Architectural and Engineering Design Process to Support Sustainable Construction. J. Constr. Eng. Manag. 2018, 144, 04018026. [CrossRef]

69. Ramly, Z.M.; Shen, G.Q.; Yu, A.T.W. Critical Success Factors for Value Management Workshops in Malaysia. J. Manag. Eng. 2015, 31, 05014015. [CrossRef]

70. HBK Contracting. Project Quality Plan Main Works for Lusail Stadium and Precint; HBK Contracting: Doha, Qatar, 2017.

71. Newton, L.A.; Christian, J. Impact of Quality on Building Costs. J. Infrastruct. Syst. 2006, 12, $199-206$. [CrossRef]

72. Love, P.E.D.; Mandal, P.; Li, H. Determining the Causal Structure of Rework Influences in Construction. Constr. Manag. Econ. 1999, 17, 505-517. [CrossRef]

73. WBDG. Building Commissioning. Available online: https://www.wbdg.org/building-commissioning (accessed on 5 January 2020).

74. Reed, W.; Gordon, E. Integrated Design and Building Process: What Research and Methodologies Are Needed? Build. Res. Inf. 2000, 28, 325-337. [CrossRef]

75. Robichaud, L.; Anantatmula, V.S. Greening Project Management Practices for Sustainable Construction. J. Manag. Eng. 2011, 27, 48-57. [CrossRef]

76. O'Connor, J.; Choi, J.; Winkler, M. Critical Success Factors for Commissioning and Start-Up of Capital Projects. J. Constr. Eng. Manag. 2016, 142, 04016060. [CrossRef] 
77. Kuo, R.; Low, B. Comprehensive Commissioning Benefits for Building Owners during Design, Construction, and Beyond. In Proceedings of the Ports 2016: Port Planning and Development, New Orleans, LA, USA, 12-15 June 2016; pp. 459-467. [CrossRef]

78. Forgues, D.; Iordanova, I.; Valdivesio, F.; Staub-French, S. Rethinking the Cost Estimating Process through 5D BIM: A Case Study. In Proceedings of the Construction Research Congress 2012: Construction Challenges in a Flat World, West Lafayette, IN, USA, 21-23 May 2012.

79. Ahn, Y.; Jung, C.; Suh, M.; Jeon, M. Integrated Construction Process for Green Building. Procedia Eng. 2016, 145, 670-676. [CrossRef]

80. Horman, M.J.; Riley, D.R.; Lapinski, A.R.; Korkmaz, S.; Pulaski, M.H.; Magent, C.S.; Luo, Y.; Harding, N.; Dahl, P.K. Delivering Green Buildings: Process Improvements for Sustainable Construction. J. Green Build 2006, 1, 123-140. [CrossRef]

81. Hwang, B.-G.; Tan, J. Green Building Project Management: Obstacles and Solutions for Sustainable Development. Sustain. Dev. 2010. [CrossRef]

82. Darko, A.; Chan, A.P.C.; Ameyaw, E.E.; He, B.-J.; Olanipekun, A.O. Examining Issues Influencing Green Building Technologies Adoption: The United States Green Building Experts Perspectives. Energy Build. 2017, 144, 320-332. [CrossRef]

83. Eldemerdash, J.; Mohamed, L. Exploring Obstacles of Employing Environmental Practices: The Case of Egyptian Green Hotels. J. Hum. Resour. Hosp. Tour 2013, 12, 243-258. [CrossRef]

84. Chan, A.P.C.; Darko, A.; Ameyaw, E.E.; Owusu-Manu, D.-G. Barriers Affecting the Adoption of Green Building Technologies. J. Manag. Eng. 2017, 25, 167-179.

85. Barber, P.; Graves, A.; Hall, M.; Sheath, D.; Tomkins, C. Quality failure costs in civil engineering projects. Int. J. Qual. Reliab. Manag. 2000, 17, 479-492. [CrossRef]

86. Tayyab, A.; Ajibade, A. Project Delivery Attributes Influencing Green Building Project Outcomes: A Review And Future Research Directions. Built Environ. Proj. Asset Manag. 2017, 7, 471-489. [CrossRef]

87. Raouf, A.M.; Al-Ghamdi, S.G. Effectiveness of Project Delivery Systems in Executing Green Buildings. J. Constr. Eng. Manag. 2019, 145, 03119005. [CrossRef]

88. Mesa, H.; Molenaar, K.; Alarcón, L. Exploring Performance of the Integrated Project Delivery Process on Complex Building Projects. Int. J. Proj. Manag 2016, 34, 1089-1101. [CrossRef]

89. Al-Nuaimi, S.; Banawi, A.A.; Al-Ghamdi, S.G. Environmental and Economic Life Cycle Analysis of Primary Construction Materials Sourcing Under Geopolitical Uncertainties: A Case Study of Qatar. Sustainability 2019, 11, 6000. [CrossRef]

90. Chandramohan, A.; Narayanan, S.L.; Gaurav, A.; Krishna, N. Cost and Time Overrun Analysis for Green Construction Projects. Int. J. Green Econ. 2012, 6, 167-177. [CrossRef]

91. Adekanye, O.; Davis, A.; Azevedo, I. Federal Policy, Local Policy, and Green Building Certifications in the U.S. Energy Build. 2020, 209, 109700. [CrossRef]

92. Zhou, L.; Li, J.; Chiang, Y.H. Promoting Energy Efficient Building in China through Clean Development Mechanism. Energy Policy 2013, 57, 338-346. [CrossRef]

(C) 2020 by the authors. Licensee MDPI, Basel, Switzerland. This article is an open access article distributed under the terms and conditions of the Creative Commons Attribution (CC BY) license (http://creativecommons.org/licenses/by/4.0/). 